\title{
POSITIVE CORRELATION BETWEEN PROTEASOME ACTIVITY AND POLYPHENOLS IN THE TELENCEPHALON OF ADULT FEMALE MICE.
}

\section{CORRELACIÓN POSITIVA ENTRE LA ACTIVIDAD PROTEASOMAL Y LOS POLIFENOLES EN EL TELENCÉFALO DE RATONES HEMBRAS ADULTAS.}

\author{
Agustín Ramiro Miranda ${ }^{1,2}$, Mariela Valentina Cortez ${ }^{1,3}$, Silvana Valeria Serra ${ }^{2}$, Elio Andrés Soria ${ }^{1,4,5}$
}

\begin{abstract}
:
Introduction: Proteasome regulates proteostasis, and can be compromised in neurodegenerative diseases. Thus, our aim was to correlate the activity of proteasome to the level of polyphenols in telencephalon during murine adulthood. Methods: Proteasome activity, polyphenols and other variables (glucose and hydroperoxides) were analysed in Balb/c female telencephala ( $n=20$, age $=4-12$ months), using multivariate methods. Results: The following values were found: proteasome activity $=3.1 \pm 0.6 \mathrm{Fl} / \mu \mathrm{g}$ of tissue proteins, glucose $=0.1 \pm 0.0 \mu \mathrm{g} / \mu \mathrm{g}$, hydroperoxides $=363.4 \pm 96.6 \mathrm{OD} / \mathrm{\mu g}$, and polyphenols $=0.1 \pm 0.0 \mathrm{ng} / \mathrm{\mu g}$. Polyphenols reduced during aging showed a direct correlation with proteasome (Pearson's coefficient $=0.43$, $p=0.0590$, and a multivariate linear regressive coefficient $=17.85, p=0.0216$ ), with glucose and hydroperoxides being not involved $(p>0.1)$. This correlation was confirmed by partial least square regression (beta $=0.67$ ). Conclusion: Proteasome activity can be affected during ageing, and promoted by telencephalic polyphenol levels. Thus, these diet compounds might exert benefits in adult brain.
\end{abstract}

Palabras clave: central nervous system; aging; proteostasis; phytochemicals; multivariate statistics.

\section{Resumen:}

Introducción: El proteasoma regula la proteostasis y puede verse comprometido en enfermedades neurodegenerativas. Por lo tanto, nuestro objetivo fue correlacionar la actividad del proteasoma con el nivel de polifenoles en el telencéfalo durante la edad adulta de ratones. Métodos: Se analizaron la actividad del proteasoma, polifenoles y otras variables (glucosa e hidroperóxidos) en telencéfalos de ratones hembras Balb/c ( $n=20$, edad $=4-12$ meses), utilizando métodos multivariados. Resultados: Se encontraron los siguientes valores: actividad proteasomal $=3,1 \pm 0,6 \mathrm{Fl} / \mu \mathrm{g}$ de proteínas tisulares, glucosa $=0,1 \pm 0,0 \mu \mathrm{g} / \mu \mathrm{gg}$, hidroperóxidos $=363,4 \pm 96,6 \mathrm{OD} / \mathrm{\mu g}$ y polifenoles $=0,1 \pm 0,0 \mathrm{ng} / \mathrm{\mu g}$. Los polifenoles reducidos durante el envejecimiento mostraron una correlación directa con el proteasoma (coeficiente de Pearson $=0,43$, $p=0,0590$ y un coeficiente de regresión lineal multivariante $=17,85, p=0,0216$ ). Glucosa e hidroperóxidos no estuvieron implicados ( $>0,1)$. Esta correlación fue confirmada por regresión parcial de mínimos cuadrados (beta $=0,67)$. Conclusión: La actividad proteasomal puede afectarse durante el envejecimiento y ser promovida por el nivel telencefálico de polifenoles. Así, estos compuestos dietéticos podrían ser beneficiosos para el cerebro adulto.

Keywords: sistema nervioso central; envejecimiento; proteostasis; fitoquímicos; estadística multivariada.

\section{Graphical abstract:}

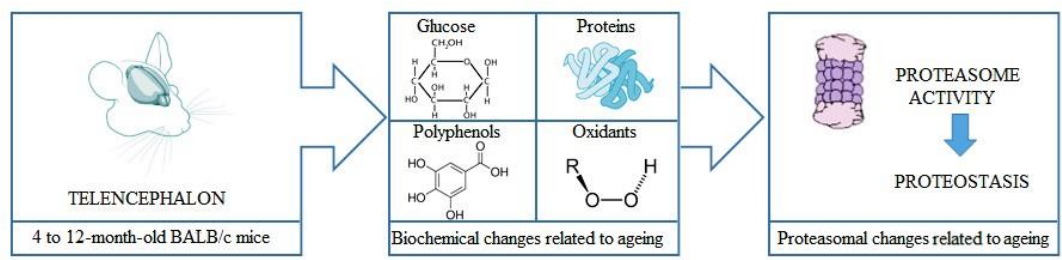

1. Consejo Nacional de Investigaciones Científicas y Técnicas, CONICET, INICSA. Bv. de La Reforma, Ciudad Universitaria, Córdoba 5014, Argentina.

2. Universidad Nacional de Córdoba. Facultad de Ciencias Médicas. Escuela de Fonoaudiología. Bv. de La Reforma, Ciudad Universitaria, Córdoba 5014, Argentina.

3. Universidad Nacional de Córdoba. Facultad de Ciencias Médicas. Escuela de Nutrición, CENINH. Bv. de La Reforma, Ciudad Universitaria, Córdoba 5014, Argentina.

4. Universidad Nacional de Córdoba. Facultad de Ciencias Médicas. Cátedra de Biología Celular, Histología y Embriología, Instituto de Biología Celular. Bv. de La Reforma, Ciudad Universitaria, Córdoba 5014, Argentina.

5. Email de contacto: easoria@fcm.unc.edu.ar 


\section{Introduction}

Proteasome is crucial for cellular proteostasis, by removing abnormal and unnecessary proteins ${ }^{1}$, such as those involved in cell cycle, apoptosis, transcription, DNA repair, protein quality control, antigenic presentation, and differentiation ${ }^{2}$. Proteasome is a 26S multicatalytic protease with a $20 \mathrm{~S}$ proteolytic core and two 195 regulatory caps $^{3}$. Different agents compromise this structure and functions, leading to pathological development ${ }^{4}$. Concerning this, deficient proteostasis is associated with mitochondrial dysfunction, oxidative stress, and apoptosis ${ }^{5}$, which is implicated in neurodegenerative diseases and other age-related pathologies ${ }^{6}$. Senescence impairs therefore proteasome activity by different mechanisms with the consequent brain damage ${ }^{7}$.

Dietary plant compounds, such as glucose and polyphenols, arrive at brain and modify its age-dependent metabolism and redox state, which might affect the activity of proteasome ${ }^{8}$. Given the relation of oxidative metabolism and proteostasis ${ }^{7,9}$, their markers should be analysed together. Furthermore, polyphenols are antioxidant and chemopreventive phytochemicals ${ }^{10}$, with multitarget neuroactivity in the central nervous system ${ }^{11}$. In consequence, the aim of the present study was to correlate proteasome activity and polyphenols in murine female telencephalon using multivariate methods to integrate different concerns.

\section{Methods}

\section{Conditions}

Healthy adult female Balb/c mice ( $n=20$, age range $=4-12$ months, body weight range $=18-26 \mathrm{~g}$ ) were maintained under physiological conditions supported by ad libitum access to standard diet $(200 \pm 13 \mathrm{~g} / \mathrm{Kg} / \mathrm{d}$; Cargill SACl, Argentina) and potable water $(150 \pm 10 \mathrm{~mL} / \mathrm{Kg} / \mathrm{d}$; Aguas Cordobesas SA, Argentina), a lightdark cycle, avoiding overcrowding in cages. They were sacrificed by isoflurane inhalation, with all procedures being in accordance with ethical concerns and good laboratory practices (86/609/CEE).

Proteasome activity (response), glucose, polyphenols (dietary plant compounds), and hydroperoxides (oxidative markers) were in telencephala (weight $=150.9 \pm 5.6 \mathrm{mg}$, protein content determined by the Biuret's reaction $=13.2 \pm 1.2 \mu \mathrm{g} / \mathrm{mg}$ of tissue), using a GloMax $\circledast$ Multi Microplate Multimode Reader (Promega Corp., Madison, WI, USA), and chemicals from Sigma-Aldrich Co. (St. Louis, MO, USA).

Telencephalic samples were homogenised at $4{ }^{\circ} \mathrm{C}$ in a solution of $50 \mathrm{mM}$ Tris and $5 \mathrm{mM} \mathrm{MgCl}_{2}(\mathrm{pH} 7.5$ by $\mathrm{HCl}$ addition), to determine proteasome and glucose. Another aliquot $(400 \mu \mathrm{L})$ was incubated for 30 minutes at $37^{\circ} \mathrm{C}$ in darkness with methanol $(600 \mu \mathrm{L})$ and $50 \%$ trichloroacetic acid $(50 \mu \mathrm{L})$, to obtain the supernatant by centrifugation ( 5 minutes at $10000 \mathrm{rpm}$ ) and determine polyphenols and hydroperoxides.

\section{Proteasome activity}

A mixture of $8 \mu \mathrm{L}$ of homogenate and $2 \mu \mathrm{L}$ of glycerol was incubated for 2 hours at $37^{\circ} \mathrm{C}$ in darkness with $100 \mu \mathrm{L}$ of substrate $(0.3 \mathrm{mM}$ Z-Leu-Leu-7-amido-4-methylcoumarin, $50 \mathrm{mM}$ Tris, $10 \mathrm{mM} \mathrm{MgCl}, 1 \mathrm{mM}$ 1,4dithiothreitol). Reaction was stopped with $200 \mu \mathrm{L}$ of $4^{\circ} \mathrm{C}$ ethanol, to measure the methylcoumarin-amide product as fluorescence intensity (FI, spectrofluorometry: Ex $380 \mathrm{~nm} / \mathrm{Em} 440 \mathrm{~nm})^{12}$.

\section{Polyphenols}

Supernatants $(100 \mu \mathrm{L})$ were mixed with $0.1 \%$ Fast Blue BB $(10 \mu \mathrm{L})$ and $20 \%$ sodium bicarbonate $(10 \mu \mathrm{L})$ for $30 \mathrm{~min}$ in darkness at $37^{\circ} \mathrm{C}$. Polyphenols were measured at $450 \mathrm{~nm}$ and calculated according to a standard gallic acid curve ${ }^{13}$.

\section{Hydroperoxides}

These oxidative markers were analyzed in $10 \mu \mathrm{L}$ of supernatant mixed with $100 \mu \mathrm{L}$ of chromogen (100 mM sorbitol and $0.125 \mathrm{mM}$ xylenol orange) and $1 \mu \mathrm{L}$ of catalyser ( $25 \mathrm{mM}$ ferrous ammonium sulphate in $2.5 \mathrm{M}$ sulphuric acid). After 30 minutes at room temperature, optical density (OD) was measured at $540 \mathrm{~nm}^{14}$.

\section{Glucose}

The Trinder's method was used using a commercial kit according to a previous work ${ }^{14}$. Results at $540 \mathrm{~nm}$ were calculated according to a standard glucose curve. 


\section{Statistical analysis}

Proteasome data were analyzed with different statistical methods using the Infostat v.2012 software as previously done ${ }^{15}$. Variables were correlated by the Pearson's coefficient followed by the path analysis to discriminate interactions of these correlations. Also, age was categorised according to the mean $<$ or $\geq 7.6$ \pm 0.5 months as younger and older mice, respectively, for $T$ test. Multivariate linear regression was used to confirm results, and partial least squares regression to obtained betas in case of covariate predictors ${ }^{16}$.

\section{Results}

The following values were found per $\mu \mathrm{g}$ of tissue proteins: proteasome activity $=3.1 \pm 0.6 \mathrm{FI}(40.6 \pm 5.4$ $\mathrm{Fl} / \mathrm{mg}$ of tissue), glucose $=0.1 \pm 0.0 \mu \mathrm{g}(0.8 \pm 0.1 \mu \mathrm{g} / \mathrm{mg})$, polyphenols $=0.1 \pm 0.0 \mathrm{ng}(1.4 \pm 0.2 \mathrm{ng} / \mathrm{mg})$, and hydroperoxides $=363.4 \pm 96.6 \mathrm{OD}(3361.7 \pm 436.6 \mathrm{OD} / \mathrm{mg})$. No significant differences in proteasome activity were found according to age $(p=0.2473$, Table 1$)$.

Table 1. Neurochemical variables found in telencephala of female Balb/c mice $(n=20)$

\begin{tabular}{lll}
\hline & \multicolumn{1}{c}{ Younger mice* } & \multicolumn{1}{c}{ Older mice** } \\
\hline \multirow{2}{*}{ Proteasome activity } & $3.5 \pm 0.9 \mathrm{FI} / \mu \mathrm{g}$ of proteins & $2.9 \pm 0.7 \mathrm{FI} / \mu \mathrm{g}$ of proteins \\
& $(33.9 \pm 7.4 \mathrm{FI} / \mathrm{mg}$ of tissue $)$ & $(44.9 \pm 7.4 \mathrm{FI} / \mathrm{mg}$ of tissue $)$ \\
\hline \multirow{2}{*}{ Glucose } & $0.1 \pm 0.0 \mu \mathrm{g} / \mu \mathrm{g}$ of proteins & $0.1 \pm 0.0 \mu \mathrm{g} / \mu \mathrm{g}$ of proteins \\
& $(0.7 \pm 0.1 \mu \mathrm{g} / \mathrm{mg}$ of tissue $)$ & $(0.9 \pm 0.1 \mu \mathrm{g} / \mathrm{mg}$ of tissue $)$ \\
\hline \multirow{2}{*}{ Polyphenols } & $0.2 \pm 0.0 \mathrm{ng} / \mu \mathrm{g}$ of proteins & $0.1 \pm 0.0 \mathrm{ng} / \mu \mathrm{g}$ of proteins \\
& $(1.6 \pm 0.2 \mathrm{ng} / \mathrm{mg}$ of tissue $)$ & $(1.2 \pm 0.2 \mathrm{ng} / \mathrm{mg}$ of tissue $)$ \\
\hline \multirow{2}{*}{ Hydroperoxides } & $327.0 \pm 87.7 \mathrm{OD} / \mu \mathrm{g}$ of proteins & $383.0 \pm 143.4 \mathrm{OD} / \mu \mathrm{\mu g}$ of proteins \\
& $(3235.0 \pm 659.3 \mathrm{OD} / \mathrm{mg}$ of tissue $)$ & $(3430.0 \pm 588.4 \mathrm{OD} / \mathrm{mg}$ of tissue $)$ \\
\hline
\end{tabular}

Pearson's coefficient of proteasome activity and age was $-0.14(\mathrm{p}=0.5464)$. This weak inverse correlation was indirect and mainly depended on aging-related reduction of polyphenols $(-0.10$ of -0.14$)$. Moreover, the proteasome-polyphenol coefficient was direct and equal to $0.43(\mathrm{p}=0.0590)$. Although hydroperoxides and glucose were reciprocally correlated (coefficient $=0.92, p<0.0001$ ), they were not associated with proteasome $(p>0.7)$ and age $(p>0.8)$ (Table 2).

Table 2: Path analysis of proteasome activity $(\mathrm{FI} / \mu \mathrm{g}$ of proteins, $\mathrm{n}=\mathbf{2 0})$

\begin{tabular}{llcc}
\hline \multicolumn{1}{c}{ Effect } & \multicolumn{1}{c}{ Path } & Coefficient & p-value \\
\hline Polyphenols $(\mathrm{ng} / \mu \mathrm{g})$ & Direct & 0.65 & \\
Polyphenols $(\mathrm{ng} / \mu \mathrm{g})$ & Body weight $(\mathrm{g})$ & -0.15 & \\
Polyphenols $(\mathrm{ng} / \mu \mathrm{g})$ & Age $($ months $)$ & 0.01 & \\
Polyphenols $(\mathrm{ng} / \mu \mathrm{g})$ & Glucose $(\mu \mathrm{g} / \mu \mathrm{g})$ & -0.19 & \\
Polyphenols $(\mathrm{ng} / \mu \mathrm{g})$ & Hydroperoxides $(\mathrm{OD} / \mu \mathrm{g})$ & 0.11 & \\
\hline Total correlation & & $\mathbf{0 . 4 3}$ & $\mathbf{0 . 0 5 9}$ \\
\hline Body weight $(\mathrm{g})$ & Direct & 0.43 & \\
Body weight $(\mathrm{g})$ & Polyphenols $(\mathrm{ng} / \mu \mathrm{g})$ & -0.24 & \\
Body weight $(\mathrm{g})$ & Age $($ months $)$ & -0.02 & \\
Body weight $(\mathrm{g})$ & Glucose $(\mu \mathrm{g} / \mu \mathrm{g})$ & 0.12 & \\
Body weight $(\mathrm{g})$ & Hydroperoxides $(\mathrm{OD} / \mu \mathrm{g})$ & -0.13 & \\
\hline Total correlation & & $\mathbf{0 . 1 5}$ & $\mathbf{0 . 5 2 3}$ \\
\hline Age $(\mathrm{months})$ & Direct & -0.06 & \\
Age $($ months) & Polyphenols $(\mathrm{ng} / \mu \mathrm{g})$ & -0.13 & \\
Age $($ months) & Body weight $(\mathrm{g})$ & 0.13 & \\
Age $($ months $)$ & Glucose $(\mu \mathrm{g} / \mu \mathrm{g})$ & -0.06 & \\
Age $($ months) & Hydroperoxides $(\mathrm{OD} / \mu \mathrm{g})$ & -0.02 & \\
\hline Total correlation & & $\mathbf{- 0 . 1 4}$ & $\mathbf{0 . 5 4 6}$ \\
\hline Glucose $(\mu \mathrm{g} / \mu \mathrm{g})$ & Direct & -0.62 & \\
Glucose $(\mu \mathrm{g} / \mu \mathrm{g})$ & Polyphenols $(\mathrm{ng} / \mu \mathrm{g})$ & 0.21 & \\
Glucose $(\mu \mathrm{g} / \mu \mathrm{g})$ & Body weight $(\mathrm{g})$ & $-0,08$ & \\
Glucose $(\mu \mathrm{g} / \mu \mathrm{g})$ & Age $($ months) & -0.00 & \\
Glucose $(\mu \mathrm{g} / \mu \mathrm{g})$ & Hydroperoxides $(\mathrm{OD} / \mu \mathrm{g})$ & 0.41 & \\
\hline Total correlation & & $\mathbf{- 0 . 0 8}$ & $\mathbf{0 . 7 2 4}$ \\
\hline Hydroperoxides $(\mathrm{OD} / \mu \mathrm{g})$ & Direct & 0.45 & \\
\hline
\end{tabular}




\begin{tabular}{llcc} 
Hydroperoxides $(\mathrm{OD} / \mu \mathrm{g})$ & Polyphenols $(\mathrm{ng} / \mu \mathrm{g})$ & 0.17 & \\
Hydroperoxides $(\mathrm{OD} / \mu \mathrm{g})$ & Body weight $(\mathrm{g})$ & -0.13 & \\
Hydroperoxides $(\mathrm{OD} / \mu \mathrm{g})$ & Age $($ months $)$ & 0.00 & \\
Hydroperoxides $(\mathrm{OD} / \mu \mathrm{g})$ & Glucose $(\mu \mathrm{g} / \mu \mathrm{g})$ & -0.57 & \\
\hline Total correlation & & $\mathbf{- 0 . 0 7}$ & $\mathbf{0 . 7 5 8}$ \\
\hline
\end{tabular}

Multivariate linear regression of proteasome activity modelled age (months), body weight (g), polyphenols $(\mathrm{ng} / \mu \mathrm{g})$ and glucose $(\mu \mathrm{g} / \mu \mathrm{g})$ as independent variables, which respectively showed these regressive coefficients: $-0.13(p=0.6216), 0.42(p=0.1319), 17.85(p=0.0216)$ and $-10.98(p=0.4064)$. Regression was repeated using hydroperoxides instead of glucose, given their covariation, with similar results and a nule regressive coefficient for these oxidative markers ( $p=0.6189)$ (Figure 1).
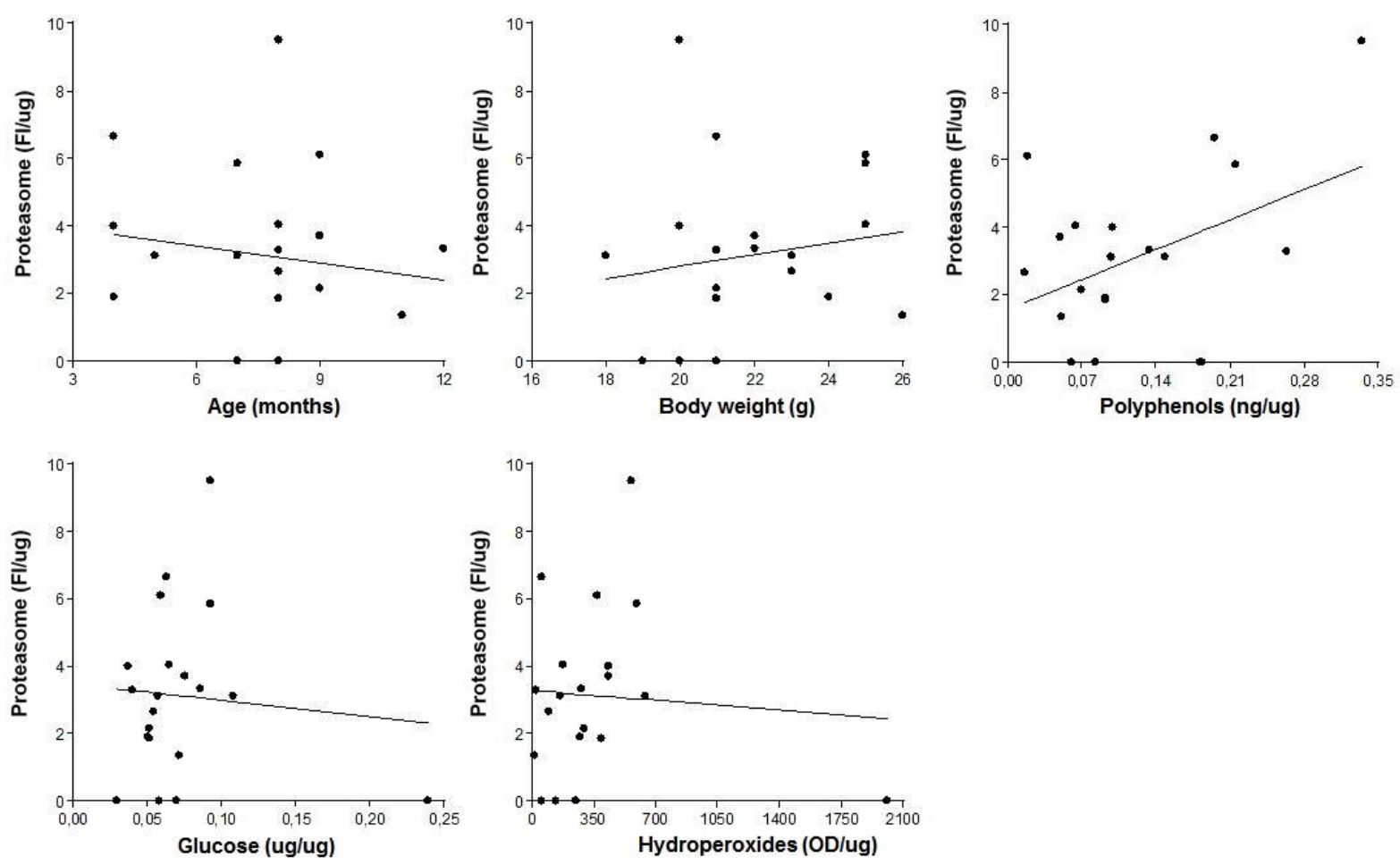

Figure 1. : Linear regression of proteasome activity $(\mathrm{Fl} / \mathrm{?g}$ of proteins, $\mathrm{n}=\mathbf{2 0})$ according to different variables.

PLS allowed modelling age categories, glucose, hydroperoxides, body weight, polyphenols (predictors), telencephalic weight and proteasome activity, to confirm that this activity correlated to polyphenols (beta=0.67), which decreased in telencephalon during aging (Figure 2).

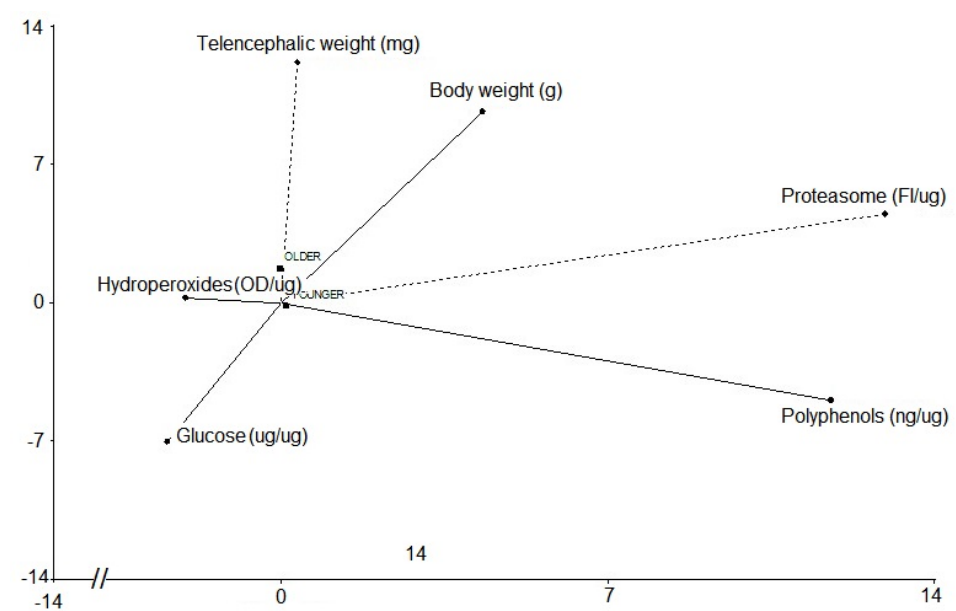

Figure 2. Partial least square regression of proteasome activity $(\mathrm{Fl} / \mathrm{?g}$ of proteins, $\mathrm{n}=\mathbf{2 0}$ ) and telencephalic weight (mg) according to different variables. 


\section{Discussion}

Although the synthesis of proteasome can be reduced during aging, this is compensated in brain by proteasome plasticity ${ }^{17}$. Activity is therefore conserved, as demonstrated here. Proteasome deficiency has been also reported, but it is described by univariate methodology under pathological conditions, which disturb proteostasis by different mechanisms ${ }^{18}$. Moreover, healthy conditions were supported by the no involvement of glucose and hydroperoxide, which are dysmetabolic markers ${ }^{19}$. Contradictory data about age-related proteasome compromise are revised by Dantuma and Bott in accordance with different experimental conditions $^{20}$.

The neuroprotective activity of polyphenols depends on their capacity to stabilise degradation machinery and promote quality control of proteins with subsequent increase of lifespan ${ }^{21}$. Accordingly, polyphenols are neurotropic compounds ${ }^{11}$, which showed a positive relation with proteasome in the current work. Telencephalic decrease of these compounds during aging can respond to changes on their organic absorption and distribution. A diet supply might be therefore suggested to prevent brain-affecting noncommunicable diseases ${ }^{11}$. Summing up, healthy female mice do not exhibit proteasome modifications during the first year of life, which supports the concept of normal ageing at molecular level, when appropriate diet compound supply is given.

\section{Bibliography:}

1. Finley D. Recognition and processing of ubiquitin-protein conjugates by the proteasome. Annu Rev Biochem. 2009;78:477-513.

2. Saez I, Vilchez D. The mechanistic links between proteasome activity, aging and age-related diseases. Curr Genomics 2014;15:38-51.

3. Glickman $\mathrm{MH}$, Ciechanover A. The ubiquitin-proteasome proteolytic pathway: destruction for the sake of construction. Physiol Rev. 2002;82:373-428.

4. Romanucci M, Della Salda L. Oxidative stress and protein quality control systems in the aged canine brain as a model for human neurodegenerative disorders. Oxid Med Cell Longev. 2015;2015:940131.

5. Fourcade S, Ferrer I, Pujol A. Oxidative stress, mitochondrial and proteostasis malfunction in adrenoleukodystrophy: A paradigm for axonal degeneration. Free Radic Biol Med. 2015;88:18-29.

6. Wang F, Lerman A, Herrmann J. Dysfunction of the ubiquitin-proteasome system in atherosclerotic cardiovascular disease. Am J Cardiovasc Dis. 2015;5:83-100.

7. Dasuri K, Zhang L, Keller JN. Oxidative stress, neurodegeneration, and the balance of protein degradation and protein synthesis. Free Radic Biol Med. 2013;62:170-85.

8. Triplett JC, Tramutola A, Swomley A, Kirk J, Grimes K, Lewis K, Orr M, Rodriguez K, Cai J, Klein JB, Perluigi M, Buffenstein R, Butterfield DA. Age-related changes in the proteostasis network in the brain of the naked mole-rat: Implications promoting healthy longevity. Biochim Biophys Acta 2015;1852:2213-24.

9. Shang F, Taylor A. Ubiquitin-proteasome pathway and cellular responses to oxidative stress. Free Radic Biol Med. 2011;51:516.

10. Kim DH, Surh YJ. Chemopreventive and therapeutic potential of phytochemicals targeting cancer stem cells. Curr Pharmacol Rep. 2015;1:302-11.

11. Miranda AR, Cortez MV, Albrecht C, Soria EA. Pharmacology and toxicology of polyphenols with potential as neurotropic agents in non-communicable diseases. Curr Drug Targets 2016. doi:10.2174/1389450117666161220152336.

12. Hobler SC, Williams A, Fischer D, Wang JJ, Sun X, Fischer JE, Monaco JJ, Hasselgren PO. Activity and expression of the $20 \mathrm{~S}$ proteasome are increased in skeletal muscle during sepsis. Am J Physiol. 1999;277:434-40.

13. Medina MB. Simple and rapid method for the analysis of phenolic compounds in beverages and grains. $J$ Agric Food Chem. 2011;59:1565-71.

14. Cortez MV, Soria EA. The effect of freeze-drying on the nutrient, polyphenol, and oxidant levels of breast milk. Breastfeed Med. 2016;11:551-54.

15. Soria EA, Pérez RD, Queralt I, Pérez CA, Bongiovanni GA. Immunotoxicological effects of arsenic bioaccumulation on spatial metallomics and cellular enzyme response in the spleen of male Wistar rats after oral intake. Toxicol Lett. 2017;266:65-73.

16. Sæbø S, Almøy T, Flatberg A, Aastveit AH, Martens H. LPLS-regression: a method for prediction and classification under the influence of background information on predictor variables. Chemometr Intell Lab. 2008;91:121-32.

17. Dasuri K, Zhang L, Ebenezer P, Liu Y, Fernandez-Kim SO, Keller JN. Aging and dietary restriction alter proteasome biogenesis and composition in the brain and liver. Mech Ageing Dev. 2009;130:777-83.

18. Guo JL, Lee VM. Cell-to-cell transmission of pathogenic proteins in neurodegenerative diseases. Nat Med. 2014;20:130-38.

19. Fisher-Wellman KH, Ryan TE, Smith CD, Gilliam LA, Lin CT, Reese LR, Torres MJ, Neufer PD. A direct comparison of metabolic responses to high-fat diet in C57BL/6J and C57BL/6NJ mice. Diabetes 2016;65:3249-61.

20. Dantuma NP, Bott LC. The ubiquitin-proteasome system in neurodegenerative diseases: precipitating factor, yet part of the solution. Front Mol Neurosci. 2014;7:70.

21. Hajieva P. The effect of polyphenols on protein degradation pathways: implications for neuroprotection. Molecules 2017;22:159. 